\title{
Identifying opportunities to improve management of water stress in banana production
}

\author{
Niranjan Panigrahi*, Andrew J. Thompson*, Sergio Zubelzu** and Jerry W. Knox*† \\ *School of Water, Energy and Environment, Cranfield University, Cranfield, MK43 OAL, UK \\ **Departamento de Ingeniería Agroforestal, Universidad Politecnica de Madrid, Ciudad Universitaria \\ s/n, 28040, Madrid, Spain
}

†Corresponding author: j.knox@cranfield.ac.uk

\begin{abstract}
Banana (Musa spp.) is one of the most valuable global agricultural commodities, with commercial plantations responsible for supplying nearly $15 \%$ of total global banana production. These plantations are underpinned by major infrastructural investments and a high dependence on fertilizer, pesticide and irrigation inputs. In contrast, smallholders and subsistence farmers often cultivate bananas for local markets with minimal inputs. Water stress due to increasing rainfall variability and competition for water resources are emerging as major production constraints for both commercial and smallholder production. Water stress-induced yield losses of up to $65 \%$ have been reported due to loss in bunch weight even in moderate to low rainfall areas. Thus, investments in more efficient irrigation systems and water-saving technologies are being widely promoted to increase water productivity through improved scheduling to reduce drainage and runoff losses. This paper synthesises scientific and industry evidence on crop growth and development including root and shoot development, plant water relations, and yield response to water. It also critiques the importance of irrigation scheduling for maximising irrigation efficiency. New evidence to support the synchronization of irrigation with crop water demand to reduce environmental impacts is provided. High variability in crop water demand (1200 to $2690 \mathrm{~mm}$ per year) was
\end{abstract}


found to be linked to cultivar choice, crop development cycle, and fluctuating conditions in environmental and edaphic factors. The findings confirm that irrigation should be scheduled at moderate levels of soil water deficit sufficient to promote deep and extensive rooting while maintaining banana quality. Management practices are recommended to mitigate water stress without compromising yield under limited rainfall and irrigation conditions. The ratooning cycle of banana also affects rooting activity and crop coefficients $\left(\mathrm{K}_{\mathrm{c}}\right)$ compared to other annual crops. These aspects need to be considered when improving irrigation and crop modelling for banana. The findings provide valuable new insights and evidence for scientists and practitioners involved in banana research and management.

Keywords: Agriculture; irrigation; scheduling; soil management; yield

\section{Introduction}

Banana is a fruit crop with the highest global production (127.3 million tonnes), and ranked fourth in terms of agricultural commodity value (63.6 billion US\$) after rice, wheat and milk (Ploetz et al., 2015; FAOSTAT, 2018). India contributes nearly a third (29\%) of total global production, followed by China, the Philippines, Brazil and Ecuador (Figure 1). Given its concentration in tropical regions, $15 \%$ of total production is exported to non-producing regions with the remaining produce then traded in domestic markets for local consumption (Heslop-Harrison, 2009; Varma and Bebber, 2019). In addition to market demands (export, local or subsistence), banana production also depends on various factors including cultivar type, agroclimatic conditions, soil type and disease risk. Broadly, the systems for banana cultivation and management are classified based on climate (tropical or subtropical) and type (dessert or cooking) (Purseglove, 1972; Stover and Simmonds, 1987). Among the different production systems, tropical bananas for export are mainly dessert and grown in Central and South America, the Caribbean, West Africa and Philippines. These are of the Cavendish subgroup (Musa AAA) and form the basis of major part of traded (15\%) and local consumption 
(28\%) worldwide (Ploetz et al., 2015). Bananas are also important for income generation and employment for millions of households and a significant source of foreign currency for countries such as Ecuador, Philippines, Costa Rica, and Colombia.

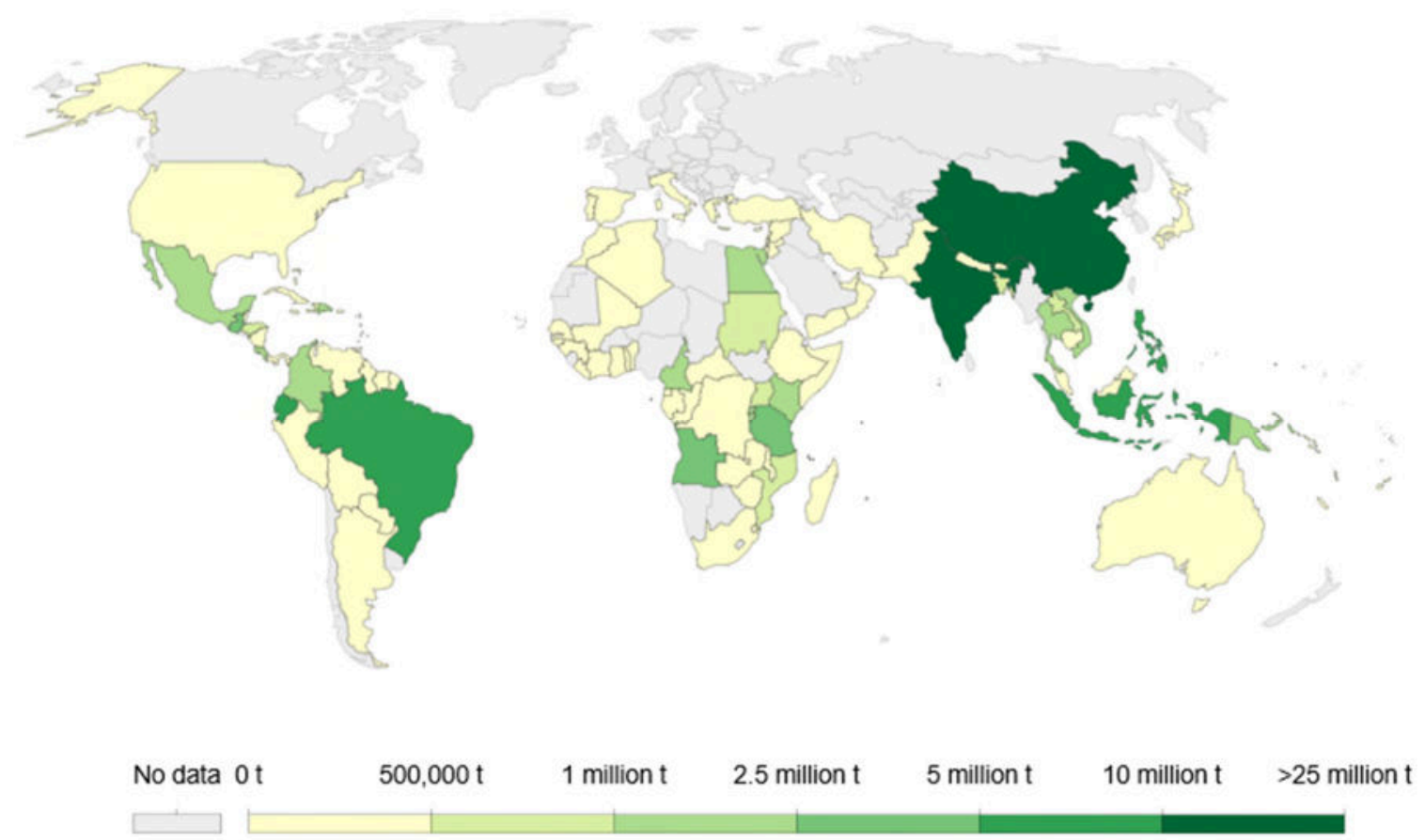

Figure 1 Global banana production (million tonnes) in 2014. Data sources: UN FAO and Ritchie (2014).

Banana production is divided into two distinct systems, (i) large scale commercial agro-export orientated plantation estates, and (ii) smallholder farms typically acting as 'outgrowers' for the larger estates. The latter are typically owned by multi-national companies which control production, transport and distribution of bananas with high levels of output supported by significant infrastructural investment. Most plantations are large (>1000 ha) and equipped with extensive infrastructure to support high quality production (Robinson and Sauco, 2010; Wiley, 2008). In contrast, smallholder family farms typically have areas of 10 to 50 ha and do not meet export market criteria because of their low output and traditional management techniques (Wunder, 2001). Quality fruit production for market export depends on five main factors: (a) soils and plant nutrition, (b) drainage and irrigation, (c) types of cultivars grown 
(d) planting densities and sucker management; and (e) disease management. A deficiency in any of these factors may negatively impact on fruit quality and yield.

Water scarcity is a major threat to global agriculture and defined as a shortage of water in the root zone resulting in reduced crop yields (Salekdeh et al., 2009). Global climate changerelated events such as extreme weather are predicted to increase: precipitation intensities will be heavier and dry spells will be longer over the $21^{\text {st }}$ century (Fischer et al., 2013; Wang et al., 2017). The magnitude of these events is also expected to increase which will exacerbate the sustainability of many agricultural systems and threaten long-term productivity and food security (IPCC, 2014). The projected increase in dry spells will increase evapotranspiration (ET) rates which when combined with unevenly distributed rainfall will deplete soil moisture and lead to increased crop water stress. Irrigation will inevitably become more important as a buffer against more extreme climate variability and rainfall uncertainty.

Bananas have a high demand for water with supplemental irrigation often needed to maximise yield (Kumaran and Muthuvel, 2009; Pawar et al., 2017). Originally grown in tropical regions, cultivation has expanded across a much wider range of both tropical and sub-tropical climates exposing production to extended dry periods (Stover and Simmonds, 1987; Van Wesemael et al., 2019). In contrast to many other crops, banana has a development cycle from transplanting to harvest of circa 10-14 months under optimum conditions, but this can be delayed when crop water supply is unreliable (Robinson, 1996; Van Wesemael et al., 2019). According to Van Asten et al. (2011), a deficit of $100 \mathrm{~mm}$ monthly rainfall during the banana crop cycle can reduce bunch weight up to $9 \%$. It has also been reported that regions with less than 1100 mm year $^{-1}$ rainfall may suffer yield losses of between $20-65 \%$ compared to yield potential. Climate models predict a $50 \%$ increase in yield and lands suitable for bananas in the subtropics and the tropical highlands due to the increase in temperature and precipitation by 2070 (Calberto et al., 2015). Varma and Bebber, (2019) reported that global banana yield 
changes are driven by an increase in temperature over the recent past. However, temperature increases will correspondingly lead to increased irrigation water demands (Adhikari et al., 2015), which are projected to rise by +12 to $+15 \%$ (Washington and Pearce, 2012). Higher temperatures will also increase pest and disease risks. In this context, the aim of this paper was to critically review and assess evidence on crop growth including shoot and root development and specifically the phenological aspects that are directly impacted by abiotic stress and irrigation management. Developing an improved understanding of these aspects will be fundamental in formulating strategies to mitigate future climate and water-related production risks.

\section{Crop growth and development}

This section focuses on the growth and development of both vegetative and reproductive structures of Cavendish subgroup bananas in the context of water stress. Banana is different from other annual crops because of its ratooning (Figure 2): initially a clonally propagated mother plant is transplanted and develops to produce the "mother plant crop" (MC), meanwhile successive suckers arising from the mother plant rhizome are then selected for regrowth which give rise to successive ratoon crops ( $\mathrm{RC} 1, \mathrm{RC} 2$ etc.). After a mother plant or ratoon is harvested, it is kept in place to support the supply of water and nutrients for the next succession of suckers through their strong vascular connection (Lassoudière, 1980; Stover and Simmonds, 1987). Unwanted suckers are removed to avoid the competition for water, light and nutrients. Ratooning is important for commercial banana production as it facilitates multiple cropping for many years and helps to reduce field management inputs. However, after 3 to 8 ratooning cycles, the plants need to be replaced with disease-free transplants to avoid a gradual yield decline (Heslop-Harrison, and Schwarzacher, 2007). The duration of each crop cycle depends on soil fertility, agronomic practices (e.g. mulching) and selection of healthy suckers (Blomme et al., 2008). 


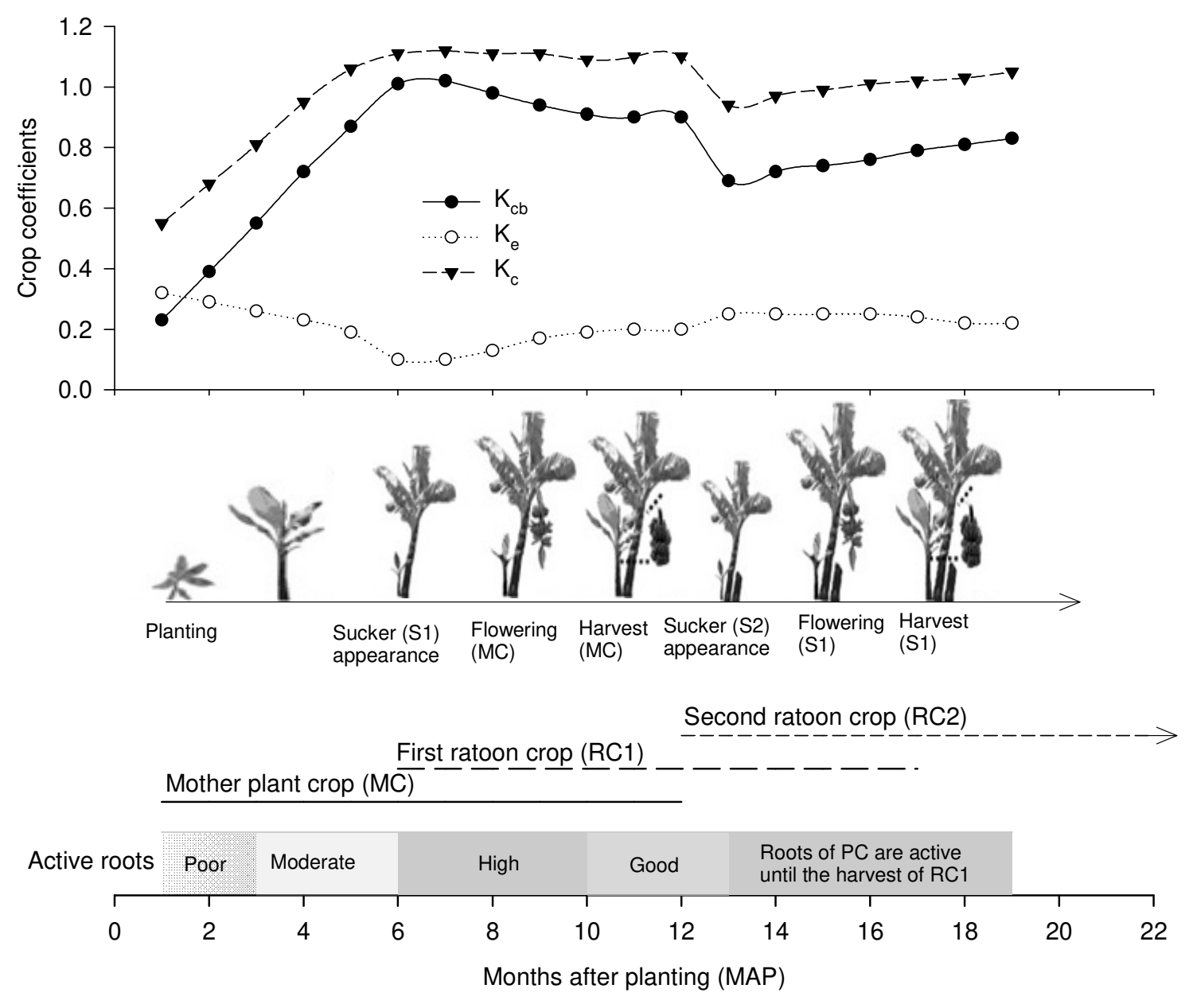

Figure 2 Typical banana ratooning system and rooting activity with three growing cycles showing mother plant crop (MC), first ratoon crop (RC1) and second ratoon crop (RC2) and corresponding crop coefficient (Kc) values. Adapted from Santosh and Tiwari (2019).

\subsection{Shoot development}

The main banana aerial shoot is a pseudostem that initiates from the apical meristem of the rhizome (below ground stem). The main shoot grows to a height of 2 to $8 \mathrm{~m}$ depending on the cultivar (Carr, 2009), and is determinate. Subsequent growth occurs via development of suckers (also known as "followers") from the lateral buds on the rhizome (Norman et al., 1984). The pseudostem is composed of the rolled and encircled leaf sheaths that emerge from the compact true stem at the base of the pseudostem; the internodes in this true stem remain very short (Carr, 2009). The vertical physical support of the shoot is entirely dependent on the 
leaf sheaths of the pseudostem. The leaf area of an individual mature leaf and a whole plant varies between 2 to $3 \mathrm{~m}^{2}$ and 17 to $25 \mathrm{~m}^{2}$, respectively (Stover and Simmonds 1987). Depending on the cultivar, growing season and plant density, the leaf area index (LAI) of an individual plant canopy may reach five at maturity in well-managed plantations (Stevens et al., 2020). A LAI of 4.5 was reported to be optimum for a banana canopy to intercept about 90\% of total incoming solar radiation (Turner, 1990; Turner et al., 2007).

Water stress in banana is visually apparent as reduced growth and reduced leaf size, and increased leaf senescence (Kallarackal et al., 1990; Turner and Thomas, 1998). Wilting and tearing of the leaves (laminae tear into strips) are also indicators of water stress under windy and hot dry conditions (Taylor and Sexton, 1972). Tearing of leaves reduces the net photosynthesis rate of the plant by transforming the leaves into small leaflets (Turner, 1997). In sub-tropical South Africa, severe leaf tearing is often associated with smaller plants, reduced leaf areas and a reduction in rates of photosynthesis (Eckstein et al., 1996). The most sensitive indicator of soil water deficit stress is the rate of emergence of new leaves (Kallarackal et al., 1990; Hoffmann and Turner, 1993; Turner and Thomas, 1998). For example, emergence of new leaves was observed to stop in container-grown Cavendish plants in Australia when a soil water potential (SWP) of $-65 \mathrm{kPa}$ occurred for 2 to 10 days in a rapidly drying soil with evaporation rates of 8 to $10 \mathrm{~mm} \mathrm{day}^{-1}$, but not at a SWP of $-50 \mathrm{kPa}$ for 25 days in a slowly drying soil with evaporation rates of 3 to $4 \mathrm{~mm} \mathrm{day}^{-1}$ (Hoffman and Turner, 1993). It was also reported that the leaf elongation rate (typically $80 \mathrm{~mm} \mathrm{day}^{-1}$ ) from the pseudostem was reduced when soil moisture stress occurred between -10 to $-80 \mathrm{kPa}$ for container-grown Cavendish plants.

\subsection{Root development}

The banana root system is adventitious (arising from stem tissue), spreading widely and formed of abundant branching shallow roots, that results in a dense shallow rooting mat. It 
comprises adventitious root axes (cord roots), and primary and secondary laterals. The cord roots are straight and cylindrical and can grow up to a length of 3 to $5 \mathrm{~m}$ and diameter of 4 to $10 \mathrm{~mm}$ (Draye et al., 2005). Root hairs are present just behind the root apex, and measure up to $2 \mathrm{~mm}$ in length (Leville, 1964). Cord roots play a major architectural role in distributing the primary and secondary laterals in soil (Sebuwufu et al., 2004). This may imply that plants with a higher number of cord roots have the potential to increase their root length and surface area for water and nutrient absorption. The roots of larger diameter tend to concentrate near the pseudostem of the plant within a depth of $0.4 \mathrm{~m}$ (Sant'Ana et al., 2012). The primary and secondary laterals and root hairs typically remain active for 8,5 and 3 weeks, respectively (Robinson, 1987), whereas the life of cord roots for Cavendish cv 'Williams' varied from 4 to 6 months under South African conditions (Robinson, 1987). The root grows steadily until flowering. Several researchers have reported the distribution and development of banana roots in specific local environments and soil conditions (Carr, 2009). For example, Shmueli (1953) reported that the root distribution of an irrigated dwarf Cavendish variety in the Jordan Valley (Israel) was concentrated to a depth of $0.45 \mathrm{~m}$ for the mother plant, with very few roots deeper than $0.6 \mathrm{~m}$. In that study, the maximum root depth reached $0.3 \mathrm{~m}$ for suckers with 13 14 visible leaves.

The soil moisture regime has a direct effect on both the number of roots, their development and distribution (Chapion, 1968). However, limited published literature is available on banana roots and their responses to changing soil water regimes. Banana roots can extract water only at relatively high (small negative) values, typically at soil water potentials (SWP) down to -45 $\mathrm{kPa}$; this highlights their poor water absorption ability (Hedge, 1988) relative to other crops such as rice, which extract water from SWP down to -110 kPa (Dasgupta et al., 2015). In South India, Krishnan and Shanmugavelu (1980) reported the effects of root distribution of Cavendish cv. Robusta to three irrigation regimes (20, 40 and $60 \%$ depletion of available soil 
moisture). They found that the overall root biomass was not significantly affected; however, an increase in water stress resulted in slightly deeper $(0.74 \mathrm{~m})$ and wider $(3.24 \mathrm{~m})$ rooting systems than the less water-stressed plants with a depth and width of $0.69 \mathrm{~m}$ and $2.88 \mathrm{~m}$, respectively. In addition to the soil water regime, the irrigation application method, soil types and planting season also influenced the root distribution. Lahav and Kalmar (1988) reported that roots of drip-irrigated bananas (Cavendish cv. Williams) could grow vertically down to 1 $\mathrm{m}$ with $75 \%$ of roots found between 0 and $0.6 \mathrm{~m}$. The effective depth of rooting for a medium textured soil increased from $0.4 \mathrm{~m}$ at 3 months after planting to about $0.6 \mathrm{~m}$ at 12 months after planting (Bassoi et al., 2004). This rooting pattern leads to a recommended irrigation schedule assuming a rooting depth of $0.4 \mathrm{~m}$ for the first 9 months from planting and subsequently 0.6 m (Bassoi et al., 2004). Robinson and Bower (1988) observed the seasonal root growth of irrigated banana (Cavendish cv. Williams) in a field trial in Malelane, South Eastern Transvaal. In their study, they found that maximum root extensions of cord roots $(275 \mathrm{~mm}$ week $^{-1}$ ) occurred in late summer (daily evaporative demand of $8 \mathrm{~mm}$ ) before declining during the autumn (daily evaporative demand of $5 \mathrm{~mm}$ ). The root extensions during late summer may be linked to a higher transpiration rate of $0.97 \mathrm{~mm} \mathrm{~mm}^{-1}$ of potential evaporation compared to winter with a transpiration rate of $0.61 \mathrm{~mm} \mathrm{~mm}^{-1}$. Irizarry et al. (1981) studied root distributions in banana grown in three different soil types (Ultisols, Entisols and Inceptisols) at five different locations in the humid tropics. The concentration of cord roots decreased with soil depth for all soil types. Most of the roots were distributed within 0 to $0.3 \mathrm{~m}$ and were rarely were found below $0.45 \mathrm{~m}$ where there was a relatively impermeable soil layer. A summary of published literature on banana root distribution characteristics in relation to different soil types is summarised in Table 1. It should be noted, however, that root distribution is also dependent on any constraints in top and sub-soil depth and resistance, not 
only on intrinsic developmental pre-programmed growth; the characteristics of specific soil profiles may therefore explain different observations from different studies and locations.

Table 1 Synthesis of evidence on banana rooting distributions for different soil types.

\begin{tabular}{|c|c|c|c|}
\hline $\begin{array}{l}\text { Rooting distribution and depth } \\
\text { characteristics }\end{array}$ & Soil type & Location & Reference \\
\hline $12 \%$ of roots distributed below $0.6 \mathrm{~m}$ & $\begin{array}{l}\text { Sandy clay } \\
\text { loam }\end{array}$ & Costa Rica & $\begin{array}{l}\text { Araya et al., } \\
\text { (1998) }\end{array}$ \\
\hline $\begin{array}{l}\text { Most roots within } 0-0.15 \mathrm{~m} \text { and no roots } \\
\text { observed below } 0.8 \mathrm{~m}\end{array}$ & Ultisol & Nigeria & $\begin{array}{l}\text { Blomme } \\
\text { and Ortiz, } \\
\text { (1996) }\end{array}$ \\
\hline $\begin{array}{l}\text { Most roots distributed within } 0.6 \mathrm{~m} \text { vertically } \\
\text { and } 0.5 \mathrm{~m} \text { laterally }\end{array}$ & $\begin{array}{l}\text { Sandy clay } \\
\text { loam soil }\end{array}$ & Brazil & $\begin{array}{l}\text { Silva et al., } \\
(2013)\end{array}$ \\
\hline $\begin{array}{l}80 \% \text { of roots at } 0.61 \mathrm{~m}, 0.51 \mathrm{~m} \text { and } 0.61 \mathrm{~m} \\
\text { depth and distance of } 0.63 \mathrm{~m}, 0.66 \mathrm{~m} 0.79 \mathrm{~m} \\
\text { from the pseudostem for drip, micro and } \\
\text { conventional sprinkler irrigated crops, } \\
\text { respectively }\end{array}$ & $\begin{array}{l}\text { Medium } \\
\text { textured } \\
\text { latosol }\end{array}$ & Brazil & $\begin{array}{l}\text { Sant' Ana et } \\
\text { al., (2012) }\end{array}$ \\
\hline $\begin{array}{l}\text { Until } 91 \text { days after planting, most roots } \\
\text { observed to a vertical depth of } 0.4 \mathrm{~m} \text {; roots also } \\
\text { extended to } 0.6 \mathrm{~m} \text { prior to harvest }\end{array}$ & $\begin{array}{l}\text { Medium } \\
\text { textured } \\
\text { latosol }\end{array}$ & Brazil & $\begin{array}{l}\text { Bassoi et } \\
\text { al., (2004) }\end{array}$ \\
\hline $\begin{array}{l}\text { Roots grow vertically to a depth of } 1 \mathrm{~m} \text { with } \\
75 \% \text { in the top } 0.6 \mathrm{~m} \text { in drip-irrigated bananas }\end{array}$ & $\begin{array}{l}\text { Brown } \\
\text { vertisol soil }\end{array}$ & Israel & $\begin{array}{l}\text { Lahav and } \\
\text { Kalmar } \\
\text { (1988) }\end{array}$ \\
\hline $\begin{array}{l}88 \%, 9 \% \text { and } 3 \% \text { of the vertical root } \\
\text { distribution with soil depths of } 0-0.6 \mathrm{~m}, 0.6-0.8 \\
\mathrm{~m} \text { and }>0.8 \mathrm{~m} \text {, respectively }\end{array}$ & Silty clay & $\begin{array}{l}\text { South } \\
\text { Africa }\end{array}$ & $\begin{array}{l}\text { Robinson, } \\
\text { (1996) }\end{array}$ \\
\hline $\begin{array}{l}\text { Effective root zone depth for bananas is within } \\
0.4 \text { to } 0.6 \mathrm{~m}\end{array}$ & $\begin{array}{l}\text { Sandy loam } \\
\text { soil }\end{array}$ & $\begin{array}{l}\text { South } \\
\text { Africa }\end{array}$ & $\begin{array}{l}\text { Robinson } \\
\text { and Alberts, } \\
\text { (1989) }\end{array}$ \\
\hline Roots extended to a depth of $0.6 \mathrm{~m}$ & $\begin{array}{l}\text { Alluvial } \\
\text { clay loam } \\
\text { soil }\end{array}$ & Australia & $\begin{array}{l}\text { Daniells, } \\
1986\end{array}$ \\
\hline
\end{tabular}




\subsection{Flower development}

The Cavendish subgroup typically produces 40-50 leaves before floral initiation in lowland tropical areas (Carr, 2009). Floral development involves elongation of internodes of the true stem and its emergence through the cylindrical core formed by the leaf sheaths of the pseudostem. The period from floral initiation to bunch emergence is termed the floral phase. The flowers are arranged in nodal clusters in two rows on transverse cushions (crown) of an inflorescence (Carr, 2009). The first nodes of the flowers are female and the last nodes are male. Female flowers develop into fruit without pollination (Purseglove, 1972). The inflorescence on a banana plant behaves positively geotropically by hanging in a pendulous position. Water stress during flowering affects the bunch growth and the flower numbers. In one study on St Lucia using Cavendish cv. Robusta, Holder and Gumps (1982) reported a significant reduction in the number of female flowers in continuously water-stressed plants (not irrigated throughout) compared to well-watered plants (SWP > -50 kPa and available soil moisture above $75 \%$ ). That study also reported that an unlimited irrigation supply for 120 to 180 days after planting, coinciding with flowering can increase the production of female flowers by up to $8.6 \%$ and $34 \%$ compared to continuously watered (irrigated) and continuously water stressed (unirrigated) plants, respectively.

\subsection{Fruit development}

Individual flowers develop into fingers which are then clustered together in a node (known as "hand") with multiple nodes comprising a bunch. The interval between inflorescence (bunch) emergence to harvest is seasonally variable, ranging from 90 to 110 days during summer season to 200 days during autumn season crops grown in the tropics and sub-tropics. The average bunch mass of the Cavendish subgroup in the tropics varies between $30-35 \mathrm{~kg}$, but may reach up to $50 \mathrm{~kg}$ in the subtropics for ratoon crops (Robinson and Nel, 1989; Carr, 2009). Goenaga and Irizarry (2000) reported that water stress applied by reducing the average 
monthly irrigation application from 202.2 litre/plant to 50.2 litre/plant in Cavendish cultivars could reduce the absolute bunch yield up to $18 \%, 37.9 \%$ and $37.4 \%$ for plant crop, first ratoon and second ratoon, respectively. Water stress before bunch emergence reduced the number of hands and fingers; however, water stress after bunch emergence reduced the size of fingers and delayed the fruit filling (Watson and Daniells, 1983; Mahouchi, 2007). In a study at the National Research Centre for Banana (India) water stress was imposed by withholding drip irrigation at the flowering stage, which decreased bunch weight by $42 \%$ for Cavendish cv. Robusta (Ravi et al., 2013). The size of fingers and bunch fresh weight of banana cv. Grand Naine were reduced by $9 \%$ and $41 \%$, respectively, after a continuous water stress treatment (gravimetric soil moisture reduced to $15 \%$ ) was applied by withholding irrigation for 63 days after bunch emergence (Mahouachi, 2007).

\section{Plant water relations}

The water relations of a plant describe the combined effects of soil moisture availability, evaporative demand, internal hydraulic resistance and uptake capacity of roots. Banana contains laticifers (secretory cells producing latex) in the leaves, fruit and rhizome and these pose problems for the use of standard methods to measure water relations in the plant (Turner and Thomas, 1998). Despite the challenges posed from laticifers, the refractive index of exuded latex was correlated with water potential (Milburn et al. 1990; Thomas and Turner, 2001). Subsequently, several other methods for measurements of the volumetric (leaf water content, specific leaf water content and relative water content) or thermodynamic (leaf water, osmotic and pressure potentials) tissue water status have been developed (Turner et al., 2007). In addition, the plant morphological techniques for measuring the extent of leaf folding and leaf (young) emergence have also been developed (Milburn et al., 1990; Thomas and Turner, 1998; Zimmerman et al., 2010). However, all the above methods are destructive. Therefore, Lu et al., (2002) used a non-destructive sap flow method by measuring heat dissipation 
through the insertion of probes into the central cylinder of the banana rhizome to estimate water flow from the root system to the shoot.

The most important physiological indicators used in experiments to manage water stress in bananas are stomatal conductance and net photosynthesis. These have a higher correlation with soil water potential from -1 to $-60 \mathrm{kPa}$ than leaf water status (Carr, 2009). Stomatal conductance reduced to $50 \%$ with a soil water potential of $-65 \mathrm{kPa}$, which corresponded to approximately $54 \%$ depletion of available soil water compared to field capacity (Robinson and Bower, 1988). The leaf water potential for well-watered bananas varied by up to -0.35 MPa. Based on a water stress trial in South Africa on Cavendish cv. Williams, Eckstein et al., (1996) recommended limiting the irrigation interval to 3 days and ensuring the SWP did not go beyond -15 to $-20 \mathrm{kPa}$ during the summer and autumn periods in order to maintain photosynthesis and leaf gas exchange rates. It was also reported that the SWP can be extended from -30 to $-35 \mathrm{kPa}$ during winter with no severe reduction in photosynthetic potential. Similarly, in another field experiment in Western Australia, Thomas and Turner (1998) reported that the net photosynthesis rate only reduced when the SWP exceeded $-30 \mathrm{kPa}(0.3 \mathrm{~m}$ soil depth) for Cavendish cv. Williams.

\section{Crop water requirements}

According to FAO 56, the crop water requirement is defined as the evapotranspiration losses from a well-watered crop under non-limiting soil conditions (Allen et al., 1998). This is fundamentally important for irrigation scheduling, as irrigation must substitute any soil water deficit arising from evapotranspiration losses. Relative to other crops, evapotranspiration amounts for banana varied have been reported to vary between $1200 \mathrm{~mm}$ and $2690 \mathrm{~mm}$ per year depending on soil and agroclimatic conditions (Robinson and Alberts, 1987). The high variability in evapotranspiration is also linked to the perennial herbaceous nature of the crop and their broad leaves which can take more than a year to complete a life cycle (Robinson, 
1995). Under semiarid conditions, the average monthly water requirement of $138 \mathrm{~mm}$ per plant can be used for optimal production of drip-irrigated bananas (Gonegas and Izziary, 2000). It has also been observed that the monthly water requirement of bananas grown in an ultisol (clayey-mixed) is twice that of plants grown in an oxisol (fine soils with low clay content) (69 mm) and half of that of plants that grown in mollisols (humus rich soils) (277 $\mathrm{mm})$. Under humid tropic conditions, the recommended water requirement for bananas are 1 to 1.4 of Class A pan evaporation (Stover and Simmonds, 1987; Diczbalis and Toohill, 1993). Purseglove (1978) estimated the minimal water requirement to be $25 \mathrm{~mm}$ per week with an average of 2000-2500 mm per year to achieve good growth. As a rule of thumb, in rainfed areas, a seasonal uniform rainfall of $>100 \mathrm{~mm}$ per month throughout the year is essential for banana growth and production, although this depends on soil water holding capacity and crop rooting depth, and the environmental conditions that drive evapotranspiration (Ravi and Vaganan, 2016). Krishnan (1977) reported that a Cavendish cv. Robusta consumed $2150 \mathrm{~mm}$ water during the growing season to produce a good crop while maintaining $20 \%$ depletion in available soil moisture. Bhattacharyya et al. (1985) reported consumptive use of water to be up to $1560 \mathrm{~mm}$ for the Cavendish cultivar for soils kept at $20 \%$ depletion of soil available moisture. The wide variation of water use of bananas could be attributed to changes in cultivar, crop duration, and fluctuating conditions in environmental and edaphic factors. In addition to meeting crop evapotranspiration needs, irrigation can also be used as a means to control pest and disease risk. Irrigating soil to saturation or flooding in combination with application of soil organic matter to create anaerobic, reductive conditions, can be used to control Fusarium oxysporum (FOC), the cause of fusarium wilt, a widespread disease on bananas (Wen et al., 2015), and currently a major concern to future global banana production.

\section{Water use efficiency}


Water management for irrigated bananas under conditions of water scarcity has three major challenges, namely (i) minimising water losses, (ii) increasing yield and (iii) increasing water use efficiency (WUE) or "more crop per drop". WUE has raised significant interest due to anticipated reductions in global freshwater availability, and the need to maximise crop production per unit of water used. It can be determined at different scales (Leakey et al., 2019) but a useful agronomic measure of WUE for banana can be defined as the mass of fresh fruit per unit of water applied. Since farmers typically irrigate at much higher levels than recommended from irrigation research, WUE may be poor productivity metric (Metochis, 1999). Excess irrigation causes waterlogging and nutrient depletion and can have negative consequences on yield. Improving WUE can thus contribute to water saving, releasing water resources to irrigate additional land, but studies that estimated banana WUE remain scarce. WUE expressed in terms of the yield of ripened fruits per unit of water applied have been reported to vary between 2.8 and $3.7 \mathrm{~kg} \mathrm{~m}^{-3}$ for Cavendish cv. Robusta grown in a sandy clay loam soil at the Indian Institute of Horticultural Research in Bangalore, India (Hegde and Srinivas, 1989). In a semi-arid environment in Brazil, the WUE varied from 1.10 to $1.32 \mathrm{~kg}$ $\mathrm{m}^{-3}$ (Teixeira and Bassoi, 2009). In a separate study, Akinro et al. (2012) reported WUE for drip irrigated bananas to range between 0.91 and $1.41 \mathrm{~kg} \mathrm{~m}^{-3}$ in south west Nigeria. The reported range of WUE for bananas is much higher than for maize, which typically varies between 0.3 and $2.7 \mathrm{~kg} \mathrm{~m}^{-3}$ (Bastiaanssen et al., 2003; Igbadun et al., 2006). WUE is also influenced by traits in crop type or cultivar (e.g. rooting depth, leaf morphology and stomatal behaviour) and climate, particularly the variable vapour pressure deficit (VPD) since high temperatures and low relative humidity drive higher transpiration rates (Kissel et al., 2015) without directly influencing the assimilation of carbon. Maximum WUE of $1.43 \mathrm{~kg} \mathrm{~m}^{-3}$ and $1.39 \mathrm{~kg} \mathrm{~m}^{-3}$ were achieved for a mother crop and ratoon crop grown under a weekly irrigation schedule, which maintained the soil water deficit within 37 to $43 \%$ at $0-20 \mathrm{~cm}$ depth and 35 to 
$39 \%$ at 20-40 cm depth in a sandy loam soil in West Bengal, India (Kuna, 2014). A reduction of soil water deficits below the optimal level by $10 \%$ will decrease the WUE by up to 54.9 to $62.6 \%$ for mother crop and 53.4 to $57.7 \%$ for a ratoon crop, respectively. In the semi-arid climatic conditions in Sudan, a maximum WUE of $7.4 \mathrm{~kg} \mathrm{~m}^{-3}$ was reported in a clay soil with a hydroflume irrigation system that maintained soil water content between 40 to $62 \%$ at $0-40$ cm soil depth (Ali et al., 2015). The key options available to farmers to improve WUE relate to soil management (to improve soil water holding capacity in the root zone) and irrigation practices that match water application rates to water crop demand, crop physiology and soil capacity. These reduce non-beneficial water losses via drainage, run-off and evaporation while maintaining high growth rates.

\section{Irrigation systems}

Even with the same cultivars and growing conditions, banana yields can be highly sensitive to the choice of irrigation application system. This may be a consequence of differences in uniformity of water distribution, the soil wetted area and volume, and intensity and frequency of application, which when combined alter the spatial distribution of root system development, and the convective-dispersive flow of macro and micro-nutrients (Donato et al., 2011). The choice of irrigation system depends on numerous factors that are both site and context specific including degree of management, suitability to a particular farming system (field sizes, topography), water availability and quality, and system cost. All these factors therefore need to be considered before selecting a specific irrigation system. Drip irrigation has been reported to be the most efficient with $95 \%$ application efficiency over other methods compared to micro-irrigation (85\%) and overhead sprinklers (60\%) (Eckstein et al., 1998). In Israel, Lahav and Kalmer, (1989) reported that drip irrigation used the same amount of water as micro-sprinklers but with a reduced soil wetted volume. However, several authors have reported reduced water use with equal or improved yields under drip (Clark and Samajtrla, 
1996; Hanson and May, 2007). In subtropical South Africa, Robinson and Alberts, (1987) reported that drip irrigation was associated with a yield increment of $33 \%$ (equivalent to 40 to 50 tons $\mathrm{ha}^{-1}$ ) compared to micro-sprinklers on Cavendish cv. Williams. However, drip irrigation does not help with evaporative cooling in the subtropics compared to microsprinklers, which can reduce the canopy temperature by up to $3^{\circ} \mathrm{C}$ and help to maintain a cool and humid microclimate to support crop growth. Drip irrigation was found to be the most appropriate method for meeting the water requirement of bananas, saving $42 \%$ in the mother plant crop and $40 \%$ in a ratoon crop, compared to conventional (surface) irrigation (Pramanik and Biswas, 2012). Water savings of approximately $29 \%$ under drip irrigation have also been reported compared to surface (flood) irrigation (Narayanamoorthy, 2003). In India, most banana production uses conventional surface irrigation with water use of c570 $\mathrm{mm}$ for the mother plant crop (13 months) and $330 \mathrm{~mm}$ for a ratoon crop (11 months) (Pramanik and Patra, 2016). In the silty clay loam soils of Sudan, the amount of water saved in a drip irrigated Cavendish cv. Grand Naine crop varied between $72 \%$ and $76 \%$ when scheduled with 80 to $120 \%$ of crop evapotranspiration (ETc) compared to surface irrigated banana (Khalifa, 2006). According to Ruiz-Sanchez et al. (2005), with drip irrigation in arid and semi-arid areas, a significant improvement in root length density can occur in the wet rootzone compared to other application methods.

\section{Water stress management}

Symptoms due to water stress in banana can occur at three different levels: (i) leaf level, involving a reduction in leaf emergence rate, loss of turgor/drooping of leaves and premature senescence, yellowing and drying of young leaves, (ii) plant level, observed as a reduction in plant height and pseudostem diameter, and (iii) bunch level, expressed as a delay in bunch initiation, bunch choking and reduction in yield components such as fingers and hand size. These crop responses to water stress can inform decisions regarding crop management. In 
addition to these general symptoms, banana responds differently to water stress at different growth stages. Ravi and Vaganan, (2016) noted that water stress in banana Cavendish cv. Grand Naine in India in the third month after planting (MAP) delayed flowering initiation by 15-20 days without affecting bunch size. However, water stress at 5 MAP may result in poor bunch size with a reduction in both the size of hands and fingers. Water stress during floral differentiation, which occurs at around 5 MAP, may affect the number of hands, fingers per hand and size of fruits. In addition to fruit size and quality, water stress during flowering also delays the crop maturity date. In St Lucia, Holder and Gumbs, (1981) reported that continuous and non-limiting water supply during floral initiation and differentiation (4-5 MAP) in banana cv. Robusta significantly increased the female flower production (34.4\%) compared to an unirrigated treatment. These studies confirm that the critical period to avoid water stress is from floral initiation to physiological maturity; water stress during this time has the largest impact on yield (Bredell, 1970; Lassoudiere, 1978). Indeed, water stress during bunch development may result in poor fruit filling and lead to a reduction in fruit size and quality (Watson and Daniells, 1983; Mahouachi, 2007). It is clear that both commercial and smallholder farming operations should much greater attention to maintaining an optimum soil moisture at these stages.

Water stress on banana can also be mitigated via specific management practices. These include better agronomic management, supplementary irrigation at critical growth stages, selection of suitable irrigation systems, drought tolerant cultivars and biochemical priming of plants (Ravi and Vaganana, 2016). Among the agronomic practices, placement of suckers at $1.5 \mathrm{~m}$ depth, maintaining the optimum number of leaves (8-10) at flowering and mulching the planting area are considered important. Deep placement of suckers helps the roots to extract available soil moisture at depth during periods of water stress. Maintaining the optimum number of leaves at critical growth stages helps to provide more sunlight to the lower leaves 
as water loss through transpiration can be reduced under limited irrigation water availability.

Supplementary irrigation at critical growth stages is important in low to scarce rainfall regions (Ravi and Vaganana, 2016; Nansamba et al., 2020). Irrigation supply to maintain 80-90\% of total available soil moisture during 5-6 MAP is necessary if dry periods coincide with floral initiation and development. The irrigation interval may vary from 3 days (under high evaporative conditions on light low moisture retentive soils) to 15 days (under low evaporative conditions on high water holding capacity soils). Application of irrigation throughout the growing season is necessary before depletion of total available soil moisture reaches circa 35\%. Smaller application depths applied on more frequent intervals is considered more beneficial compared to larger application depths with long intervals particularly during periods with limited rainfall. It has also been reported that banana can be primed to be tolerant to water stress with a foliar spray containing acetyl salicylic acid, butylated hydroxyltoluene and $\mathrm{KNO}_{3}$ (Ravi et al., 2014). These management practices are relevant to both smallholders and the large commercial plantations in helping to mitigate water stress impacts on yield and crop quality.

\section{Irrigation modelling}

One of the identified important future research needs is for improved crop and irrigation modelling based on a thorough understanding of the complexities of banana production. These models could serve as an evolving theoretical framework to adapt and optimize irrigation and to transfer knowledge to different stakeholders to enhance productivity, rural livelihoods and food security. The first step in the development of a banana model under suboptimal water and nutrient conditions was by Brisson et al. (1997). They used the phasic development, leaf, and root growth data for adapting a standard crop growth simulation model STICS (simulator multidisciplinary for crop standard) to understand the role of irrigation and tillage under irrigated and rainfed conditions. They found that crop water requirements were 
not affected by tillage depth in irrigated conditions; however, they were affected by tillage under rainfed conditions, which may be due to differences in root growth distribution and nitrogen uptake between shallow and deep tillage. More recently, Van Vosselen, (2005) used the SWAP (soil water atmosphere and plant) model to calculate water consumption in banana, for comparison against traditional water balance methods. The SWAP model requires meteorological data, crop data, soil physical and hydraulic properties data to calculate water consumption compared to traditional methods which only need limited field measurements using a simple water balance equation. They also reported that the SWAP model tended to under-estimate water consumption $\left(2.8 \mathrm{~mm} \mathrm{day}^{-1}\right)$ compared to the conventional water balance approach $\left(3.2 \mathrm{~mm} \mathrm{day}^{-1}\right)$. This led the authors to conclude that the traditional method remains a very useful option, given its limited data requirements. Several studies have also used the FAO CROPWAT approach for estimating banana water requirements (Karanja, 2006; Cigales and Perez, 2011; Surendran et al., 2015). This model simulates crop water demand by calculating evapotranspiration under various climate, crop and soil conditions (Smith, 1992).

Crop evapotranspiration $\left(\mathrm{ET}_{\mathrm{c}}\right)$ represents the combined water loss due to evaporation from the soil surface and transpiration from the crop, and is calculated using the crop coefficient $\left(\mathrm{K}_{\mathrm{c}}\right)$ approach (Allen et al., 1998). ET $_{c}$ is estimated by multiplying the ET for a reference crop surface $\left(\mathrm{ET}_{\mathrm{o}}\right)$ by a conversion factor or crop coefficient $\left(\mathrm{K}_{\mathrm{c}}\right)$. ETo is defined as the ET rate from a well-watered grass actively growing and completely covering the ground. In addition, Wright (1982) proposed a modified method in which the $\mathrm{K}_{\mathrm{c}}$ values can be separated into a soil evaporation component $\left(\mathrm{K}_{\mathrm{e}}\right)$ and a crop transpiration component $\left(\mathrm{K}_{\mathrm{cb}}\right)$. The $\mathrm{K}_{\mathrm{c}}$ components $\left(\mathrm{K}_{\mathrm{e}}\right.$ and $\mathrm{K}_{\mathrm{cb}}$ ) during a banana ratooning cycle are shown in Figure 2 (Santosh and Tiwari, 2019). The $K_{c}$ pattern through the ratoons shows an initial increasing trend and then plateauing for the mother plant crop. However, it then declines when transitioning from the 
mother plant crop to the ratoon. The soil evaporation component $\left(\mathrm{K}_{\mathrm{e}}\right)$ decreases with age of plant and was relatively higher during initial developmental stages. The $\mathrm{K}_{\mathrm{c}}$ variation during ratooning would therefore be helpful in developing a banana specific irrigation scheduling model. Studies reported that the single $\mathrm{K}_{\mathrm{c}}$ approach underestimates $\mathrm{ET}_{\mathrm{c}}$ by up to $34 \%$ for soyabean compared to the dual $\mathrm{k}_{\mathrm{c}}$ approach (Majnooni-Herish et al., 2008; Odhiambo and Irmak, 2012). The single $\mathrm{K}_{\mathrm{c}}$ approach is therefore often used for irrigation planning and design but the dual $\mathrm{K}_{\mathrm{c}}$ approach is more relevant in the development of real time irrigation scheduling guidance. In terms of a banana-specific biophysical crop model, SIMBA was used to simulate yield, economic outputs and environmental risks from the interaction between banana plants, soil, water and root nematode populations (Tixier et al., 2008). The model simulated crop yield using a function between LAI at flowering stage and number of fruits per bunch. For water consumption, a simple water balance module was used but it does not unfortunately include an irrigation scheduling routine.

In addition to modelling improvements, advancements in applied remote sensing-based tools such as satellite imagery or unmanned aerial vehicles (UAV) for estimating crop evapotranspiration and crop coefficients coupled with the availability of more skilful weather forecasting offer major opportunities for improved estimations of crop water requirements and irrigation scheduling. Recent advances in sensor technologies, image analysis and computer-based decision-making also provide major scope for improving our fundamental understanding of banana crop growth and development, and in support of implementing precision agriculture technologies to support the sustainable intensification of banana production.

\section{Future drivers of change}

From a commercial banana plantation perspective, the two major drivers of change in water management are apparent. Firstly, the socio-economics that determine supply-demand 
equilibrium for an increasing global population and the pressures this exerts on crop production under conditions of increasing water scarcity and competition for limited water; and secondly, the impacts of a changing climate, with increased temperatures and rainfall uncertainty on rainfed production systems due to increased evaporative demands. Improving the commercial prospects of water management in banana requires the appropriate institutional and policy interventions to facilitate innovation and technology transfer in both the commercial plantation and small-producer farming systems. There is an urgency for improved irrigation management techniques that have been evaluated under different soil water regimes, agroclimatic conditions and at different scales of farming operation.

This review has highlighted the significant challenges facing the industry in maintaining current levels of production in the context of an increasing likelihood of water stress. Future policy responses and management strategies underpinned by fundamental and applied research need to consider (i) a greater understanding of the water stress responses of banana, such as leaf folding, leaf emergence rate, leaf wilting, and pseudostem height and diameter, which could lead to their use as indicators of water stress and triggers for farm management decisions; (ii) more widespread evaluation of drip (and other) irrigation technologies to improve irrigation efficiency; (iii) increased use of smart technologies including soil moisture sensors, weather stations, models and decision support tools, facilitated by embedded expertise from local training and extension services; (iv) improved approaches to irrigation scheduling to meet crop water demands, at optimum levels of water stress to enhance WUE; and (v) a specific focus on irrigation management during critical growth stages (floral initiation to fruit maturity) to maximise harvestable yield. Collectively, these strategies coupled with research outreach will enable commercial plantations as well as smallholders to transform their existing farming approaches into more productive and efficient systems with greater resilience to future climate and water risks. 


\section{Conclusions}

Although banana constitutes one of the most economically important global agricultural commodities, increasing water scarcity and resource stress are posing serious constraints on production within both large-scale commercial and smallholder farming systems. This paper provides a state of the art synthesis of scientific evidence on banana agronomy to support better synchronization of irrigation management with agronomic crop water demand. Investments in more efficient application systems coupled with the adoption of precision technologies are being widely promoted to increase productivity and reduce the environmental impacts associated with poor irrigation management (notably nutrient leaching and deep drainage). Our findings confirm that irrigation scheduling should allow moderate levels of soil water deficit to accrue in order to promote deeper and more extensive rooting to maximise available soil water within the rootzone. However, the ratooning cycle of banana also impacts on rooting activity and the seasonal evolution of crop coefficients $\left(\mathrm{K}_{\mathrm{c}}\right)$. These aspects warrant further research to both improve biophysical crop modelling approaches for banana and to support farming communities in building resilience to abiotic stress (drought). A combined effort from the scientific community and practitioners is urgently needed to ensure that future centres of banana production can remain both economic and sustainable.

\section{Acknowledgement}

This research was funded by Innovate UK (TS/S011986/1). The authors acknowledge FUNDEBAN our Colombian partner for assistance in sourcing relevant information related to water management in commercial banana production systems.

\section{References}

Adhikari, U., Nejadhashemi, A. P., and Woznicki, S. A., 2015. Climate change and eastern Africa: a review of impact on major crops. Food Energy Secur., 4(2), 110-132. 
Akinro, A. O., Olufayo, A. A. and Oguntunde, P. G., 2012. Crop water productivity of plantain (Musa Sp) in a humid tropical environment. J. Eng. Sci. Technol. Rev., 5(1), 19-25. Ali, A. B., Elshaikh, N. A., Shuang-En, Y., Basheer, A. K., Alnail, M., Alhadi, M. and Altayeb, O. A., 2015. Correlation between water deficiency, yield components and crop productivity of Banana. J. Environ. Agric. Sci., 4, 11-20.

Allen, R.G., Pereira, L.S., Raes, D. and Smith, M., 1998. Crop evapotranspiration: Guidelines for computing crop requirements. Irrig. Drain., Paper No. 56, FAO, Rome, Italy, pp. 300. Araya, M., Vargas, A. and Cheves, A., 1998. Changes in distribution of banana (Musa AAA cv. Valery) roots with plant height distance from the pseudostem and soil depth. Acta. Hortic., Wageningen, 490, 201-207.

Bastiaanssen, W.G..Van Dam J. C. and Droogers P., 2003. Introduction. In: J. C. Van Dam, R.S. Malik, (Eds.), water productivity of irrigated crops in Sirsa District India. Integration of remote sensing, crop and soil models and geographical information systems. pp. 11-20.

Bassoi, L. H., Silva, E. E. G. D., Ramos, C. M. C. and Sediyama, G. C., 2004. Guidelines for irrigation scheduling of banana crop in São Francisco Valley, Brazil. I-Root distribution and activity. Rev. Bras. Frutic., 26(3), 459-463.

Bhattacharyya, R. K. and Madhava Rao, V. N., 1985. Water requirement, crop coefficient efficiency of 'Robusta' banana under covers and soil moisture regimes and water-use different soil. Sci. Hortic., 25, 263-269.

Blomme, G. and Ortiz, R., 1996. Preliminary assessment of root systems morphology in Musa. In I International Symposium on Banana: I International Conference on Banana and Plantain for Africa, 540, 259-266.

Blomme, G., Swennen, R., Soka, G. E., Turyagyenda, F. L. and Tenkouano, A., 2008. Relationship between root and shoot growth traits during the plant crop and first ratoon in 
banana and plantain (Musa spp.) and its implications for perennial cultivation on degraded Ultisols in south-eastern Nigeria, J. Appl. Biosci., 8(2), 309-322.

Bredell, G.S., 1970. Water requirements of banana. Farming South Africa, 46, 17-19.

Brisson, N., Ozier-Lafontaine, H. and Dorel, M., 1997. Effects of soil management and water regime on banana growth between planting and flowering. Simulation using the STICS model. In II International Symposium on Banana: I International Symposium on Banana in the Subtropics, 490, 229-238.

Carr, M. K. V., 2009. The water relations and irrigation requirements of banana (Musa spp.). Exp. Agric., Cambridge, 45(3), 33-371.

Chapion, J., 1968. El plátano. Barcelona: Blume, pp. 247.

Cigales, M. and Pérez, O., 2011. Soil variability and water requirement of banana cultivation in a Pacific location in Mexico. Adv. Agric., 15(3), 21-31.

Clark, G. A. and Smajstrla, A. G., 1996. Design considerations for vegetable crop drip irrigation systems. Hort. Tech., 6(3), 155-159.

Daniells, J. W., 1986. Determining patterns of soil water use by bananas. In Proceedings of Symposium on Physiology of Productivity of Subtropical and Tropical Tree Fruits (Eds. B.W. Culland P. E. Page). Acta. Hortic., 175, 357- 361.

Dasgupta, P., Das, B. S. and Sen, S. K., 2015. Soil water potential and recoverable water stress in drought tolerant and susceptible rice varieties. Agric. Water Manag., 152, 110-118. Diczbalis, Y. and Toohill, B., 1993. Irrigation management of bananas in the top end. Northern territory department of primary industry and fisheries (Darwin, Australia), Agnote no- 567. 
Donato, S. L. R., Lédo, A. A., Pereira, M. C. T., Coelho, E. F., Cotrim, C. E. and Coelho Filho, M. A., 2011. Estado nutricional de bananeiras tipo Prata sob diferentes sistemas de irrigação. Pesq. Agropec. Bras., 45(9), 980-988.

Draye, X., Lecompte, F. and Pagès, L., 2005. Distribution of banana roots in time and space: new tools for an old science. Proceedings of the International Symposium, San Jose, Costa Rica, INIBAP, Montpellier, France, 58-74.

Calberto, G., Staver, C. and Siles, P., 2015. An assessment of global banana production and suitability under climate change scenarios. En Aziz Elbehri (ed.), Climate change and food systems: global assessments and implications for food security and trade. Rome, Italy: Food Agriculture Organization of the United Nations (FAO), pp. 266-291.

Eckstein, K., Fraser, C., Botha, A. and Husselmann, J., 1998. Evaluation of various irrigation systems for highest economical yield and optimum water use for bananas. In Proceedings of an International Symposium on Banana in the Subtropics (Ed. V. Galan Sauco) Acta. Hortic., 490, 147-158.

Eckstein, K., Robinson, J. C. and Fraser, C., 1996. Physiological responses of banana (Musa AAA; Cavendish subgroup) in the subtropics. V. Influence of leaf tearing on assimilation potential and yield. J. Hortic. Sci., 71, 503-514.

FAOSTAT., 2018. Food and Agricultural Organization (FAO). Retrieved from: http://www.fao.org/faostat/en/\#data.

Fischer, E., Beyerle, U. and Knutti, R., 2013. Robust spatially aggregated projections of climate extremes. Nat. Clim. Chang., 3(12), 1033-1038.

Goenaga, R. and Irizarry, H., 2000. Yield and quality of banana irrigated with fractions of Class A pan evaporation on an oxisol. Agron. J., 92(5), 1008-1012. 
Hanson, B. and May, D., 2007. The Effect of drip line placement on yield and quality of dripirrigated processing Tomatoes. Irrigat Drain Syst., 21(2), 109-118.

Hedge, D.M., 1988. Growth and yield analysis of "Robusta" banana in relation to soil water potential and nitrogen fertilization. Sci. Hortic., Amsterdam, 37(1-2), 145-155.

Hegde, D. M. and Srinivas, K., 1989. Effect of soil matric potential and nitrogen on growth, yield, nutrient uptake and water use of banana. Agric. Water Manag., 16(1-2), 109-117.

Heslop-Harrison, J. S. and Schwarzacher, T., 2007. Domestication, genomics and the future for banana. Ann. Bot., 100(5), 1073-1084.

Heslop-Harrison, J. S., 2009. Genomics, banana breeding and superdomestication. In V International Symposium on Banana: ISHS-ProMusa Symposium on Global Perspectives on Asian Challenges, 897, 55-62.

Hoffman, H. P. and Turner, D. W., 1993. Soil water deficits reduce the elongation rate of emerging banana leaves but the night/day elongation ratio remains the same. Sci. Hortic., $54(1), 1-12$.

Holder, G. D. and Gumbs, F. A., 1982. Effects of water supply during floral initiation and differentiation on female flower production by Robusta bananas. Exp. Agric., 18(2), 183-193. Igbadun H. E, Mahoa H. F., Andrew K. P. R. and Tarimo Salim A. B., 2006. Crop water productivity of an irrigated maize crop in Mkoji sub-catchment of the Great Ruaha River Basin, Tanzania. Agric. Water Manag., 85(1-2), 141-150.

IPCC., 2014. Climate Change: Synthesis Report. Contribution of Working Groups I, II and III to the Fifth Assessment Report of the Intergovernmental Panel on Climate Change [Core Writing Team, R.K. Pachauri and L.A. Meyer (eds.)]. IPCC, Geneva, Switzerland, pp. 151. Irizarry, H., Vicente-Chandler, J. and Silva, S., 1981. Root distribution of plantains growing on five soil types. J. Agr U. Puerto Rico., 65(1), 29-34. 
Kallarackal J., Milburn J.A. and Baker D.A., 1990. Water relations of the banana. III effects of controlled water stress on water potential, transpiration, photosynthesis and leaf growth. Aust. J. Plant Physiol., 17(1), 79-90.

Karanja, F., 2006. CROPWAT model analysis of crop water use in six districts in Kenya. CEEPA DP35, University of Pretoria, South Africa, pp. 1-41.

Khalifa, A. B. A., 2012. Comparison of surface and drip irrigation regimes for banana (Musa AAA) cv. Grand Nain in Gezira, Sudan, Doctoral dissertation, M. Sc. Thesis, Agricultural Research Council. Sudan Academy of Sciences (SAS), Khartoum, Sudan.

Kissel, E., Van Asten, P., Swennen, R., Lorenzen, J., and Carpentier, S. C., 2015. Transpiration efficiency versus growth: exploring the banana biodiversity for drought tolerance. Sci Hortic., 185, 175-182.

Krishnan, B. M. and Shanmugavelu, K. G., 1980. Effect of different soil moisture depletion levels on the root distribution of banana cv.'Robusta'. South Indian Hortic., 28(1), 24-25. Krishnan, B.M., 1977. Studies on the effect of different soil moisture depletion levels on the growth and development of Musa (AAA group, Cavendish sub-group) 'Robusta'. M.Sc. (Ag.) Thesis, Tamil Nadu Agricultural University.

Kumaran, S. S. and Muthuvel, I., 2009. Fertigation in second-generation T.C banana variety suited to semiarid ecosystems. J. Ecobiol., 24 (3), 245-50.

Kuna, R. K., 2014. Effect of irrigation leaf and sucker management on yield and quality of banana (Musa Spp, AAA) Var. grand naine in terai zone of West Bengal, Doctoral dissertation, Uttar Banga Krishi Viswavidyalaya.

Lahav, A. and Kalmar, D., 1988. Response of banana to drip irrigation, water amounts and fertilisation regimes. Commun. Soil. Sci. Plant Anal., 19(1), 25-46. 
Lassoudiere, A., 1978. Quelques aspects de la croissance et du development du bananier 'Poyo' en Cote d'Ivoire, 4 en 5 partie. Fruits., 33, 314-338.

Lassoudière A., 1980. Matière végétale élaborée par le bananier Poyo depuis la plantation jusqu'à la récolte du deuxième cycle. Fruits, 35, 405-446.

Leakey, A. D., Ferguson, J. N., Pignon, C. P., Wu, A., Jin, Z., Hammer, G. L. and Lobell, D. B., 2019. Water use efficiency as a constraint and target for improving the resilience and productivity of C3 and C4 crops. Annu. Rev. Plant Biol., 70, 781-808.

Leville E., 1964. Etude dela microflore des racines du bananier 'poyo'. Fruits, 19, 435-449. Lu, P., Woo, K.C. and Liu, Z.T., 2002. Estimation of whole plant transpiration of bananas using sap flow measurements. J. Exp. Bot., 53(375), 1771-1779.

Metochis, C., 1999. Water requirement and yield of banana. Technical Bulletin 203. Agricultural Research Institute, Nicosia, pp. 3-8.

Milburn J. A., Kallarackal J. and Baker D.A., 1990. Water relations of the banana. I. Predicting the water relations of the field-grown banana using the exuding latex. Funct. Plant Biol., 17, 57-68.

Mahouachi, J., 2007. Growth and mineral nutrient content of developing fruit on banana plants (Musa acuminata AAA, 'Grand Nain’) subjected to water stress and recovery. J. Hortic. Sci. Biotech., 82(6), 839-844.

Majnooni-Heris, A., Zand-Parsa, S.H., Sepaskhah, A.S., Neyshaburi, M.R. and Asadi, E., 2008.Evaluation of MSM2 model by using eater balance lystimetr in Karkaj station in Tabriz, 9th National Seminar on Irrigation and Evapotranspiration, Kerman, Iran, 5-7.

Narayanamoorthy A., 2003. Averting water crisis by drip method of irrigation: A study of two water intensive crops. Indian J. Agric. Econ, 58(3), 427-437. 
Nansamba, M., Sibiya, J., Tumuhimbise, R., Karamura, D., Kubiriba, J., and Karamura, E., 2020. Breeding banana (Musa spp.) for drought tolerance: A review. Plant Breed., 139, 685696.

Norman, M.T.J., Pearson, C.1. and Searle, P.G.E., 1984. The ecology of tropical food crops. London, Cambridge University Press, pp. 271-285.

Odhiambo, L. O. and Irmak, S., 2012. Evaluation of the impact of surface residue cover on single and dual crop coefficient for estimating soybean actual evapotranspiration. Agric. Water Manag., 104, 221-234.

Pawar, D. D., Dingre, S. K. and Bhoi, P. G., 2017. Productivity and economics of dripirrigated Banana (Musa Spp.) under different planting and fertigation techniques in subtropical India. Commun. Soil. Sci. Plant Anal., 48(4), 449-458.

Ploetz, R. C., Kema, G. H. and Ma, L. J., 2015. Impact of diseases on export and smallholder production of banana. Annu. Rev. Phytopathol., 53, 269-288.

Pramanik S. and Biswas R.K., 2012. Effect of drip-fertigation on soil moisture distribution and irrigation water use efficiency of banana in West Bengal. J. Soil Water Conserv., 11(3), 210-217.

Pramanik S. and Patra S.K., 2016. Growth, Yield, Quality and Irrigation Water Use Efficiency of Banana under Drip Irrigation and Fertigation in the Gangetic Plain of West Bengal. World J. Agric. Res., 12(3), 220-228.

Purseglove, J. W., 1972. Tropical Crops: Monocotyledons. London, Longman, 2, 633.

Ravi, I. and Vaganan, M. M., 2016. Abiotic stress tolerance in banana. In Abiotic Stress Physiology of Horticultural Crops. Springer, New Delhi, pp. 207-222. 
Ravi, I., Vaganan, M. and Mustaffa, M. M., 2014. Management of drought and salt stresses in banana. Tech Folder No. 6. National Research Centre for Banana, Thayanur Post, Tiruchirappalli, Tamil Nadu, India, pp. 1-6.

Ravi, I., Uma, S., Vaganan, M. M. and Mustaffa, M. M., 2013. Phenotyping bananas for drought resistance. Front. Physiol., 9(4), 1-15.

Ritchie, H., 2014. Global banana production, Ourworldindata.org. Retrieved from https://ourworldindata.org/grapher/banana-production.

Robinson, J. C., 1987. Root growth characteristics in banana. Institute for Tropical and Subtropical Crops, South Africa, Information Bulletin, 183, 7-9.

Robinson, J. C., 1996. Bananas and Plantains. Wallingford, UK: Cab International, pp. 238. Robinson, J. C. and Bower, J P., 1988. Transpiration from banana leaves in the subtropics in response to diurnal and seasonal factors and high evaporative demand. Sci. Hortic., 37, 129143.

Robinson, J. C. and Nel, D. J., 1989. Plant density studies with banana (cv. Williams) in a subtropical climate. II. Components of yield and seasonal distribution of yield. J. Hortic Sci., 64, 211-222.

Robinson, J.C. and Alberts, A.J., 1989. Seasonal variations in the crop water use coefficient of banana (cultivar "Williams") in the subtropics. Sci. Hortic., Amsterdam, 40(3), 215-225. Robinson, J.C., 1995. Systems of cultivation and management. In S. Gowen (ed.) Bananas and plantains. Chapman and Hall, London, UK, pp. 15-65.

Robinson, J. C. and Galán-Saúco, V., 2010. Bananas and plantains. CAB. In International, v. 19.

Ruiz-Sanchez, MC., Plana, V., Fortuno, MF., Tapia, LM., Abrisqueta, J.M., 2005. Spatial root distribution of apricot trees in different soil tillage practices. Plant Soil, 272(1-2), 211-221. 
Salekdeh, G. H., Reynolds, M.,Bennett, J. and Boyer, J., 2009. Conceptual framework for drought phenotyping during molecular breeding. Trends Plant Sci., 14(9), 488-496.

Sant'Ana, J. A. D. V., Coelho, E. F., Faria, M. A. D., Silva, E. L. D. and Donato, S. L. R., 2012. Root distribution of 'Prata-Anã' banana in the second production cycle under three irrigation systems. Rev. Bras. Frutic., 34(1), 124-133.

Santosh, D. T. and Tiwari, K. N., 2019. Estimation of water requirement of banana crop under drip irrigation with and without plastic mulch using dual crop coefficient approach. In IOP Conference Series: Environ. Earth Sci., 344(1), 12-24.

Sebuwufu, G., Rubaihayo, P. R. and Blomme, G., 2004. Variability in the root system of East African banana genotypes. Afr. Crop Sci. J., 12(1), 85-93.

Shmueli, E., 1953. Irrigation studies in the Jordan Valley 1. Physiological activity of the banana in relation to soil moisture. Bulletin of the Research Council of Israel, 3, 228-237. Silva, A. J. P. D., Coelho, E. F., Miranda, J. H. D., 2013. Efficiency of water application of irrigation systems based on micro-sprinkling in banana plantations. Sci. Agr., 70(3), 139-146. Smith, M., CROPWAT - A computer program for irrigation planning and management, Irrigation and Drainage Pap. 46, FAO, Rome, 1992.

Stevens, B., Diels, J., Vanuytrecht, E., Brown, A., Bayo, S., Rujweka, A., Richard, E., Ndakidemi, P.A., and Swennen, R., 2020. Canopy cover evolution, diurnal patterns and leaf area index relationships in a Mchare and Cavendish banana cultivar under different soil moisture regimes. Sci Hortic., 272, 109328.

Stover, R.H. and Simmonds, N.W., 1987. Bananas. Third Edition, Longman, London, pp. 67. Surendran, U., Sushanth, C. M., Mammen, G. and Joseph, E. J., 2015. Modelling the crop water requirement using FAO-CROPWAT and assessment of water resources for sustainable 
water resource management: A case study in Palakkad district of humid tropical Kerala, India. Aquat. Procedia, 4, 1211-1219.

Taylor, S. E. and Sexton, O. J., 1972. Some implications of leaf tearing in Musaceae. Ecology, 53(1), 143-149.

Tixier, P, Malézieux, E, Dorel, M. and Wery, J., 2008. SIMBA, a model for designing sustainable banana-based cropping systems. Agric. Syst., 97(3), 139-150.

Teixeira, A.D.C. and Bassoi, L.H., 2009. Crop water productivity in semi-arid regions: From field to large scales. Ann. Arid Zone, 48 (3), 1-13.

Thomas D.S. and Turner D.W., 2001. Banana (Musa sp.) leaf gas exchange and chlorophyll fluorescence in response to soil drought, shading and lamina folding. Sci. Hortic., 90 (1-2), 93-108.

Turner D.W., 1990. Modelling demand for nitrogen in the banana. Acta Hortic., 275, $497-$ 504.

Turner, D. W., 1997. Ecophysiology of bananas: the generation and functioning of the leaf canopy. In II International Symposium on Banana: I International Symposium on Banana in the Subtropics, 490, 211-222.

Turner, D. W. and Thomas, D. S., 1998. Measurements of plant and soil water status and their association with leaf gas exchange in banana (Musa spp.): a laticiferous plant. Sci. Hortic., 77, 177-193.

Turner, D. W., Fortescue, J. A. and Thomas, D. S., 2007. Environmental physiology of the bananas (Musa spp.). Braz. J. Plant Physiol., 19, 463-484.

Varma, V. and Bebber, D. P., 2019. Climate change impacts on banana yields around the world. Nat. Clim. Chang., 9(10), 752-757. 
Van Asten, P. J., Fermont, A. M. and Taulya, G., 2011. Drought is a major yield loss factor for rainfed East African highland banana. Agric. Water Manag., 98(4), 541-552.

Van Vosselen, A., Verplancke, H. and Van Ranst, E., 2005. Assessing water consumption of banana: traditional versus modelling approach. Agric. Water Manag., 74(3), 201-218.

Van Wesemael, J., Kissel, E., Eyland, D., Lawson, T., Swennen, R., and Carpentier, S., 2019. Using growth and transpiration phenotyping under controlled conditions to select water efficient banana genotypes. Front. Plant Sci., 10, 352.

Wang, X., Jiang, D. and Lang, X., 2017. Future extreme climate changes linked to global warming intensity. Sci. Bull., 62(24), 1673-1680.

Washington R. and Pearce. H., 2012. Climate change in East African agriculture: Recent trends, current projections, crop-climate suitability, and prospects for improved climate model information. CGIAR Research Program on Climate Change, Agriculture and Food Security (CCAFS), Copenhagen, Denmark.

Watson, B. J. and Daniells, J. W., 1983. Banana - Water stress effects. Aust. J. Agric. Res., $55,138-139$.

Wen, T., Huang, X., Zhang, J., Zhu, T., Meng, L. and Cai, Z., 2015. Effects of water regime, crop residues, and application rates on control of Fusarium oxysporum f. sp. cubense. Int. J. Environ. Sci., 31, 30-37.

Wiley, J., 2008. The banana: Empires, trade wars, and globalization. University of Nebraska Press, Lincoln.

Wright, J.L., 1982. New evapotranspiration crop coefficients. J. Irrig. Drain Div., E-ASCE, 108(2), 57-74.

Wunder, S., 2001. Ecuador goes bananas: incremental technological change and forest loss. Agricultural technologies and tropical deforestation, pp. 167-194. 
Zimmermann, U., Rüger, S., Shapira, O., Westhoff, M., Wegner, L. H., Reuss, R., Gessner, P., Zimmermann, G., Israeli, Y., Zhou, A., and Schwartz, A., 2010. Effects of environmental parameters and irrigation on the turgor pressure of banana plants measured using the noninvasive, online monitoring leaf patch clamp pressure probe. Plant Biol., 112(3), 424-436. 